\title{
DAMPAK PENGGUNAAN HANDPHONE TERHADAP PERILAKU BELAJAR PESERTA DIDIK DI SMA YAYASAN SUB BYAKI FYADI KABUPATEN BIAK NUMFOR
}

\author{
Beatus Mendelson Laka \\ Dosen pada Program Studi Pendidikan Guru Sekolah Dasar STKIP-Biak \\ lakamendelson@gmail.com
}

\section{ARTICLE INFO}

\section{Article History:}

Accepted 04-09-2018

Available online 02-10-2018

Keywords:

Penggunaan Handpone,

Perilaku Belajar Peserta didik

\begin{abstract}
Penggunaan Handphone di kalangan peserta didik SMA sudah menjadi hal biasa, apalagi dengan fitur-fitur canggih dalam handphone yang mampu menyimpan file-file seperti filem porno, ketergantunganketergantungan dengan fitur-fitur di dunia maya seperti facebook, twiter, instagram, BBM dan lain-lain sudah tentu mamberi dampak baik maupun tidak baik akibat penyalahgunan handphone tersebut.Tidak terkecuali peserta didik SMA Yayasan Sub Byaki Fyadi sudah tentu telah menggunakan handphone dalam aktivitas sehari-hari bahkan dalam jam-jam belajar sekalipun dalam observasi awal pada semester ganjil tahun ajaran 2016/2017 ditemukan gejala bahwa sebagian besar peserta didik SMA Yayasan Sub Byaki Fyadi sudah memakai handphone sebagai alat komunikasi bahkan sempat peneliti berinteraksi dengan beberapa peserta didik ternyata mereka mengatakan bahwa mereka menggunakan handphone untuk komunikasi dengan teman, orang tua, kakak, saudara, bahkan dengan guru mereka. Patut diduga bahwa kejadian yang terlihat di lingkungan SMA Yayasan Sub Byaki Fyadi tidak dapat terkirakan dari pengaruh negatif sebagaimana yang di kemukakan di atas. Penelitian ini bertujuan untuk (1) mengetahui bagaimana perubahan sosial dalam bidang komunikasi, (2) mengetahui seberapa besar Perubahan sosial dalam bidang komunikasi, dan (3) mengetahui bagaimana dampak penggunaan handphone terhadap perilaku belajar peserta didik di SMA Yayasan Sub Byaki Fyadi. Tipe penelitian ini merupakan penelitian deskriptif, yaitu gambaran atau lukisan secara sistematif, faktual dan akurat tentang faktor-faktor dilapangan yang berhubungan dengan kondisi di lapangan. Hasil dari penelitian ini adalah Penggunaan hanphone bagi peserta didik ada baiknya, akan tetapi ada juga buruknya. Baiknya itu jika peserta didik yang menggunakan handphone sesuai dengan fungsinya seperti, sms sama teman, sahabat serta untuk mencari tugastugas sekolah yang diberikan dari guru kepada peserta didik. Namun selain manfaat yang baik juga pasti ada buruknya seperti setiap jam pelajaran ada peserta didik yang main handphone di belakang dan tidak mendengar penyampaian materi dari guru. Kemudian setelah memiliki handphone sudah jarang belajar karena kebanyakan waktu disita oleh handphone, maka peran orang tua dan guru sangatlah penting dalam memperhatiakan jam-jam belajara peserta didik.
\end{abstract}




\section{PENDAHULUAN}

Penggunaan handphone bagi peserta didik menjadikan dunia teknologi semakin lama semakin canggih. Komunikasi yang dulunya memerlukan waktu yang lama dalam penyampaiannya, kini dengan handphone segalanya menjadi sangat cepat dan seakan tanpa jarak. Di era globalisasi sekarang ini banyak peserta didik yang menggunakan handphone dalam kegiatan sehari-hari, baik peserta didik SMP ataupun SMA telah diperbolehkan membawa handphone di sekolah. Ditinjau dari ilmu komunikasi, maka handphone bukan lagi sekedar alat komunikasi, tetapi handphone juga merupakan alat mencipta dan menghibur dengan suara, tulisan, gambar, dan video. Para peserta didik sekarang berlomba-lomba untuk memiliki handphone karena handphone bukan hanya merupakan alat komunikasi, namun dikalangan peserta didik handphone sebagai gaya hidup. Di kalangan peserta didik, penggunaan handphone sebagai alat komunikasi karena alat tersebut multifungsi. Para peserta didik dapat menggunakan teknologi ini secara positif ataupun negative tergantung pada setiap individu.

Telepon genggam atau Handphone adalah sebuah perangkat telekomunikasi elektronik yang mempunyai kemampuan dasar yang sama dengan telepon fixed line sehingga konvesional namun dapat dibawa kemana-mana (portable) dan tidak perlu disambungkan dengan jaringan telepon menggunakan kabel (nirkabel, wireless). Handphone saat ini memang bukan barang yang mewah dan aneh bagi masyarakat Indonesia.Industri handphone, bergerak sangat cepat, setara dengan melesatnya kecepatan suaranya. Kini semakin banyak teknologi pendukung yang terintegrasi dengan produk handphone, seperti radio FM, kamera digital dan pemutar MP3. Belum lagi ukuran handphone yang berlomba untuk makin kecil dan menarik. Pilihan operator dan jangkauan operator pun menjadi yang semakin banyak dipasaran, turut memanjakan konsumen.

Handphone kini bukan lagi sekadar alat untuk berkomunikasi. Namun juga sebagai gaya hidup, penampilan, tren dan prestise. Kini dunia handphone adalah dunia untuk berkomunikasi, berbagi, mencipta dan menghibur baik dengan suara, tulisan, gambar, musik maupun video Di zaman serba teknologi seperti sekarang ini, handphone atau ponsel bukanlah barang asing bagi siapapun. Bahkan, anak-anak kecil pun sudah banyak yang bermain dengan handphone. Anak-anak ini sebagai siswa di sekolah, memiliki kewajiban untuk belajar.

Berdasarkan pertimbangan tersebut diatas maka perlu dilakukan penelitian mengenai Dampak Penggunaan Handphone Terhadap Perilaku Belajar Peserta Didik di SMA Yayasan Sub Byaki Fyadi Kabupaten Biak Numfor. Penelitian ini bertujuan untuk mengetahui bagaimana perubahan sosial dalam bidang komunikasi dan dampak penggunaan handphone terhadap perilaku belajar peserta didik di SMA Yayasan Sub Byaki Fyadi Kabupaten Biak Numfor.

\section{KAJIAN PUSTAKA}

\section{Fungsi Alat Komunikasi telephone celuler}

Langit, 2010 menyatakan Ponsel atau telephone celuler kini merupakan sahabat wajib yang tidak bisa lepas dari iri masyarakat Indonesia. Berdasarkan 
paparan data Consumer Lab Ericsson, selain sebagai alat komunikasi, handphone memiliki fungsi lain. Dari riset ditahun 2009, terdapat lima fungsi handphone yang ada di masyarakat. telephone celuler yang dulunya hanya berfungsi sebagai alat komunikasi, kini pun telah berubah. Berikut persentase 5 fungsi telephone celuler bagi masyarakat Indonesia:

1. Sebagai alat Komunikasi agar tetap terhubung dengan teman ataupun keluarga $=$ $65 \%$

2. Sebagai simbol kelas masyakarat $=44 \%$

3. Sebagai penunjang bisnis $=49 \%$

4. Sebagai pengubah batas sosial masyarakat $=36 \%$

5. Sebagai alat penghilang stress $=36 \%$.

Penggunaan ponsel menjadi kebutuhan yang sangat penting bagi kehidupan saat ini yang memerlukan mobilitas tinggi. Fasilitas-fasilitas yang terdapat didalamnya pun tidak hanya terbatas pada fungsi telepon dan SMS (short messages service) saja. Ponsel dapat digunakan sebagai sarana bisnis, penyimpan berbagai macam data, sarana musik/hiburan, bahkan sebagai alat dokumentasi. Hal ini menjadikan ponsel sebagai salah satu perkembangan komunikasi yang paling aktual di Indonesia selama lebih dari lima tahun terakhir (Nurudin, 2005). Terlihat juga pada kompetitif kualitas dari berbagai merk ponsel seperti Nokia, Ericsson, Samsung, Siemens, Motorola, Alcatel, dan lain-lain. Masing-masing tidak berhenti bersaing mencari pangsa pasar melalui produk terbaru hanya dalam kurun waktu yang relatif singkat.

Simanjuntak (2004) dalam tulisannya mengenai aspek sosial telepon selular menyatakan paling tidak ada lima implikasi dari penggunaan ponsel. Pertama, terhadap setiap individu yang menggunakan ponsel tersebut. Kedua, terhadap interaksi-interaksi antar individu. Ketiga, terhadap pertemuan tatap muka. Keempat, terhadap suatu kelompok-kelompok atau organisasi. Selanjutnya yang kelima adalah terhadap sistem hubungan di organisasi dan kelembagaan-kelembagaan masyarakat. Kogoya, 2015 mengatakan bahwa.

Teknologi lahir dari pemikiran manusia yang berusaha untuk mempermudah kegiatan-kegiatannya yang kemudian diterapkan dalam kehidupan. Kini teknologi telah berkembang pesat dan semakin canggih seiring dengan perkembangan zaman sehingga terjadi penambahan fungsi teknologi yang semakin memanjakan kehidupan manusia. Salah satu contoh fasilitas canggih saat ini adalah handphone. Di awal kemunculannya, handphone hanya dimiliki oleh kalangan tertentu yang benar-benar membutuhkannya demi kelancaran pekerjaan mereka. Namun, seiring perkembangan zaman, handphone telah dimiliki oleh semua kalangan baik yang benar-benar membutuhkan maupun yang kurang membutuhkan tak terkecuali masyarakat. Kini handphone bukan lagi sekadar alat berkomunikasi, tetapi handphone juga merupakan alat untuk mencipta dan menghibur dengan suara, tulisan, gambar, dan video. Masyarakat sekarang berlomba-lomba untuk memiliki handphone karena handphone bukan 
hanya merupakan alat berkomunikasi, namun juga bagi masyarakat pada umumnya handphone sekaligus sebagai (lifestyle) gaya hidup, tren, dan prestise.

\section{Dampak Positif dan Negatif telephone celuler}

Menurut Nikmah, 2013 menyatakan bahwa handphone pada awalnya hanya digunakan oleh orang-orang yang memang benar-benar membutuhkannya, seperti para pekerja kantoran, pebisnis, pejabat atau guru. Namun, sekarang handphone tidak hanya digunakan oleh orang-orang penting saja tetapi juga anak-anak usia sekolah. Lebih parahnya lagi anak-anak usia sekolah dasar pun sudah mengenal dan menggunakan handphone atau handphone. Mengingat tujuan diciptakannya, handphone memang diharapkan bisa memberi kemudahan komunikasi kepada manusia, terutama untuk komunikasi jarak jauh. Namun ternyata hal ini juga bisa membawa dampak pada prestasi belajar peserta didik tersebut. Baik dapat meningkatkan prestasi belajarnya tetapi juga bisa menurunkan prestasi belajar peserta didik.

Handphone atau telephone celuler memiliki dampak positif dan dampak negatifnya. Yang termasuk dampak positif dari handphone diantaranya adalah:

1. Menambah pengetahuan tentang perkembangan teknologi. Teknologi selalu berkembang sesuai dengan jaman dan pola pikir manusia yang selalu menuju kearah modernisasi.Oleh sebab itu ada baiknya juga jika siswa juga mampu mengikuti perkembangan teknologi dan informasi untuk pengetahuan siswa juga.

2. Mempermudah komunikasi terutama jarak jauh. Untuk membantu siswa yang kesulitan dalam mengerjakan Pekerjaan Rumah, handphone (HP) bisa membantu menghubungi teman yang rumahnya jauh untuk bertanya Pekerjaan Rumah karena dapat menghemat waktu.

3. Memperluas jaringan persahabatan. Dengan menggunakan handphone (HP) peserta didik bisa menambah teman dengan mudah melalui telepon langsung atau pesan singkat (SMS)

4. Sebagai penghibur pada saat peserta didik jenuh belajar. Dalam handphone (HP) terdapat fitur-fitur MP3 atau game yang dapat memberi hiburan pada peserta didik sehingga apabila peserta didik mengalami kejenuhan dalam belajar peserta didik dapat mendengarkan musik atau sekedar main game.

5. Terdapat fitur internet yang dapat membantu peserta didik mencari informasi. Hal ini mampu membantu siswa untuk mencari informasi atau materi pelajaran melalui fitur internet yang terdapat di handphone (HP).

6. Memiliki banyak memory. Handphone memiliki banyak memory untuk menyimpan banyak data dengan mudah dan dapat dibawa kemana-mana, baik informasi materi pelajaran, foto-foto, video, hasil ujian, informasi tentang buku terbaru dan musik.Ini bisa digunakan untuk membantu dan mempermudah peserta didik memahami pelajaran.

Selain dampak positif dari penggunaan handphone (HP) yang cukup banyak,namun cukup banyak juga dampak negatif bagi peseerta didik yang patut di waspadai dan seharusnya di hindari, antara lain; 
1. Terdapat efek radiasi yang mampu mempengaruhi kesehatan peserta didik, sehingga sebaiknya untuk anak SD jangan diberi handphone (HP) untuk digunakan secara permanen.

2. Rawan tindak kejahatan, karena anak-anak di anggap kurang bisa menjaga diri menyebabkan anak-anak menjadi target utama dari kejahatan pencurian.

3. Mengganggu perkembangan anak, karena tidak jarang anak sekolah malah lebih tertarik melihat handphone (HP) yang bergetar ketika pelajaran berlangsung. Parahnya lagi, handphone (HP) digunakan untuk mencontek jawaban pada saat ujian akhir/nasional.

4. Handphone (HP) juga bisa mengakibatkan pemborosan, karena menambah pengeluaran untuk pulsa. Apalagi pulsa tersebut tidak digunakan dengan baik, maka akan membuang sia-sia pulsa tersebut.

5. Penyalahgunaan fitur internet Internet yang selayaknya digunakan untuk mempermudah peserta didik mencari informasi atau materi pelajaran bias disalah gunakan untuk mencari gambar atau video yang kurang baik (porno).

\section{Perilaku Belajar}

Perilaku adalah kegiatan atau aktivitas manusia, baik yang dapat diamati langsung maupun yang tidak dapat diamati secara langsung (pihak luar) (Mardiana, 2012). Dalam sosiologi, perilaku dianggap sesuatu yang tidak ditujukan kepada orang lain dan oleh karenanya merupakan suatu tindakan sosial manusia yang paling mendasar (Arifin, 2009). Menurut Hintzman dalam Syah $(2008,90)$ mendefinisikan belajar sebagai suatu perubahan yang terjadi dalam diri organisme yang disebabkan oleh pengalaman yang dapat mempengaruhi tingkah laku organisme tersebut. Perilaku belajar adalah suatu tindakan sosial manusia yang sangat mendasar dalam proses atau usaha secara sadar dengan melibatkan sosio-psikologi yang ditandai dengan perubahan perilaku sebagai hasil dari pengalaman dan latihan baik diperoleh dari pengetahuan, sikap, atau keterampilan (Arifin, 2009).

Perilaku belajar sering disebut juga kebiasaan belajar, merupakan dimensi belajar yang dilakukan individu secara berulang-ulang sehingga menjadi otomatis atau spontan (Hanifa, 2001). Dengan perilaku belajar yang baik maka peserta didik dapat meningkatkan prestasi akademik. Hal ini sependapat dengan pernyataan Mardiana (2012) yang menyatakan dengan perilaku belajar yang positif akan mendorong peserta didik mendapatkan hubungan yang baik dengan guru, maupun teman-temannya, akan tetapi jika seorang peserta didik tidak dapat menunjukkan perilaku positif, maka dia akan mengalami kesulitan dalam belajar.

\section{METODE PENELITIAN}

Tipe ini adalah penilitian deskriftif, yaitu gambaran atau lukisan secara sistematif, faktual dan akurat tentang faktor-faktor dilapangan yang berhubungan dengan hal-hal dilapangan. Arikunto (2010:240). Penelitian ini di laksanakan di SMA Yayasan Sub Byaki Fyadi Kabupaten Biak Numfor, Provinsi Papua. Waktu yang diperlukan dalam penelitian ini adalah selama satu bulan yang dimulai pada bulan Maret 2017 sampai dengan bulan April 2017. Populasi dalam penelitian ini, adalah seluruh peserta didik kelas XI SMA Yayasan Sub Byaki Fyadi. Sampel yaitu penulis 
menggunakan teknik Proposional Random Sampling. Ditetapkan sebesar $20 \%$ dari populasi. Hasilnya sebanyak 28 orang yang terdiri dari 18 orang siswa, 5 orang guru dan 5 orang tua murit sekaligus dijadikan sebagai unit analisis data. Teknik pengumpulan data berupa observasi dan wawancara langsung.

Teknik analisis data dalam penelitian ini adalah analisis Teknik analisa data yang digunakan dalam penilitian ini adalah teknik analisa data deskriptif kualitatif, dengan menggunakan tabel presentasi yang dilakukan di lapangan bahan bersama dengan proses pengumpulan data (H.Hariari Nawawi, 1995:5).

Rumus yang digunakan adalah $: \mathrm{P}=\frac{\mathrm{F}}{N} \times 100$

Keterangan : $P=$ Presentase (\%)

$F=$ Jumlah Jawaban Responden untuk setiap pertanyaan

$N=$ Banyaknya Responden

\section{HASIL DAN PEMBAHASAN}

Tahap pengumpulan data dari responden dalam hal ini adalah orang tua siswa, guru dan sisiwa SMA Yayasan Sub Byaki Fyadi, untuk mengetahui masalah-masalah belajar, maka data yang di kembalikan oleh responden diolah dan di analisis untuk mendapatkan kesimpulan sebagai hasil penilitian .

Berdasarkan data yang terkumpul melalui pedoman wawancara maka dapat di lihat hasil pengumpulan data yaitu peserta didik yang memiliki telepon genggam atau hanphone (hp). terdapat 18 responden yang memiliki handphone dengan beberapa jenis. Handphone jenis nokia ada 8 orang, samsung sebanyak 5 responden, handphone blacbery terdapat 5 responden dari hasil penelitian semua peserta didik memiliki handphone. Alasan yang disampaikan responden yang memiliki handphone Jenis Nokia adalah karena handphone tersebut memiliki harga yang murah dan untuk menelpon serta sms teman, dan keluarga. Sementara yang memiliki handphone jenis Blackberry yaitu karena dapat mempermudah yang bersangkutan untuk mencari tugas-tugas yang sulit, berkomunikasi dengan saudara dan teman-temannya. Sedangkan untuk handphone Samsung yaitu berguna dan bermanfaat bisa membuat tugas, dan berkomunikasi melalui video cal.

Peserta didik yang sering menggunakan fitur BBM sebanyak 5 responden, sedangkan yang memiliki Facebook sebanyak 10 responden. Sementara fitur game yang sering di gunakan peserta didik sebanyak 3 responden. Alasan yang di sampaikan responden yang menggunakan Fitur Facebook adalah karena bisa berkomunikasi dengan teman sekaligus bisa mendapatkan teman baru. Sementara yang menggunakan Fitur BBM adalah untuk bisa mendapatkan teman yang baru. Sedangkan yang menggunakan fitur game untuk refresing.

Adapun lamanya waktu yang di gunakan untuk chating. Dari data analisis menunjukkan bahwa terdapat 3 responden yang menggunakn waktu hanya beberapa menit saja. Sedangkan yang menggunakan waktu chating kurang dari 1 jam sebanyak 5 responden atau (28\%). 5 responden atau (28\%) yang menggunakan waktu chating lebih dari 1 jam. Sedangkan 5 responden yang menngunakan waktu chating lebih dari 2 jam yaitu (28\%). Responden yang menggunakan waktu chating lebih dari 2 jam 
alasanya adalah chating dengan teman-teman, sahabat serta keluarga. Sementara mempunyai waktu chating kurang dari 1 jam yaitu hanya mengakses ilmu pengetahuan.

Hal ini terjadi apabila mendapat teman baru di akun facebook atau BBM sehingga menggunakan waktu yang cukup lama jika ada teman yang sudah lama baru ketemu tetapi lewat dunia maya sehingga membuat chating semakin lama.

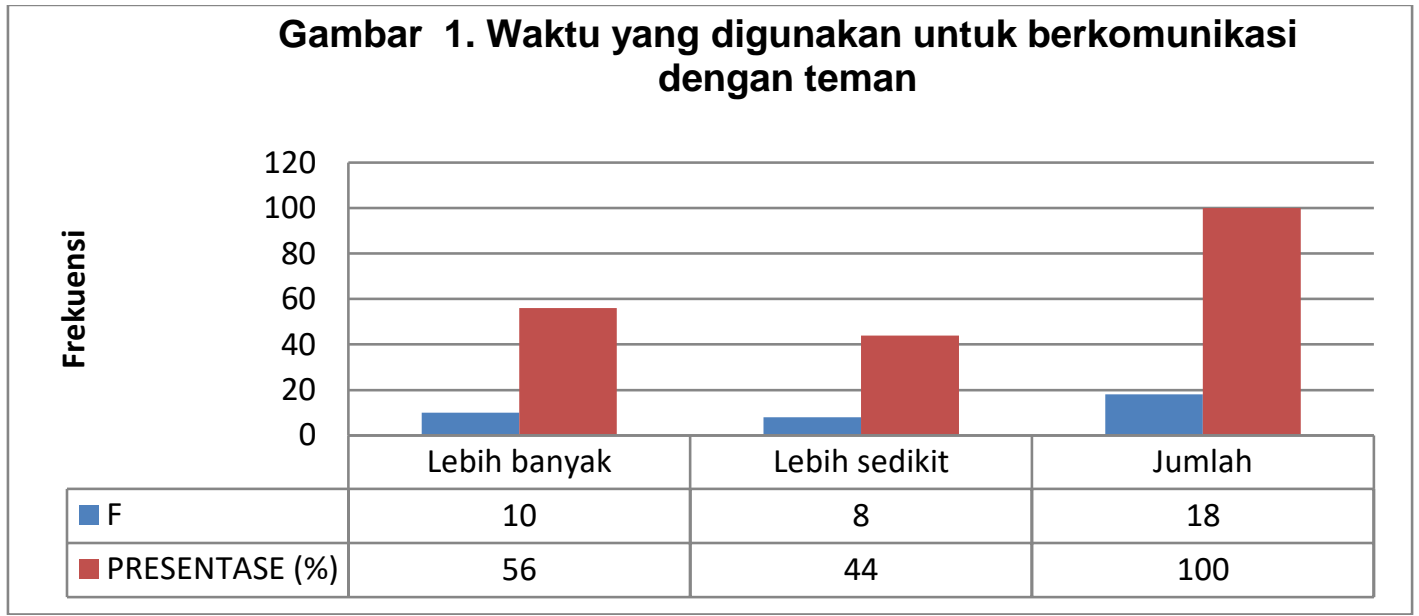

Sumber: Analisis Data Wawancara Responden

Gambar. 1 yaitu tentang waktu yang di gunakan untuk berkomunikasi dengan teman. Dari data analisis diatas menunjukkan bahwa terdapat 10 responden atau (56\%) yang lebih banyak menggunakan waktu untuk berkomunikasi dengan teman dengan alasan bahwa mereka menggunakan waktu untuk berkomunikasi dengan teman karena bagi mereka teman adalah segala-galanya. sedangkan terdapat 8 responden (44\%) yang menjawab lebih sedikit menggunakan waktu untuk berkomunikasi dengan teman. Alasanya adalah apabila mereka sedang mengerjakan tugas rumah.

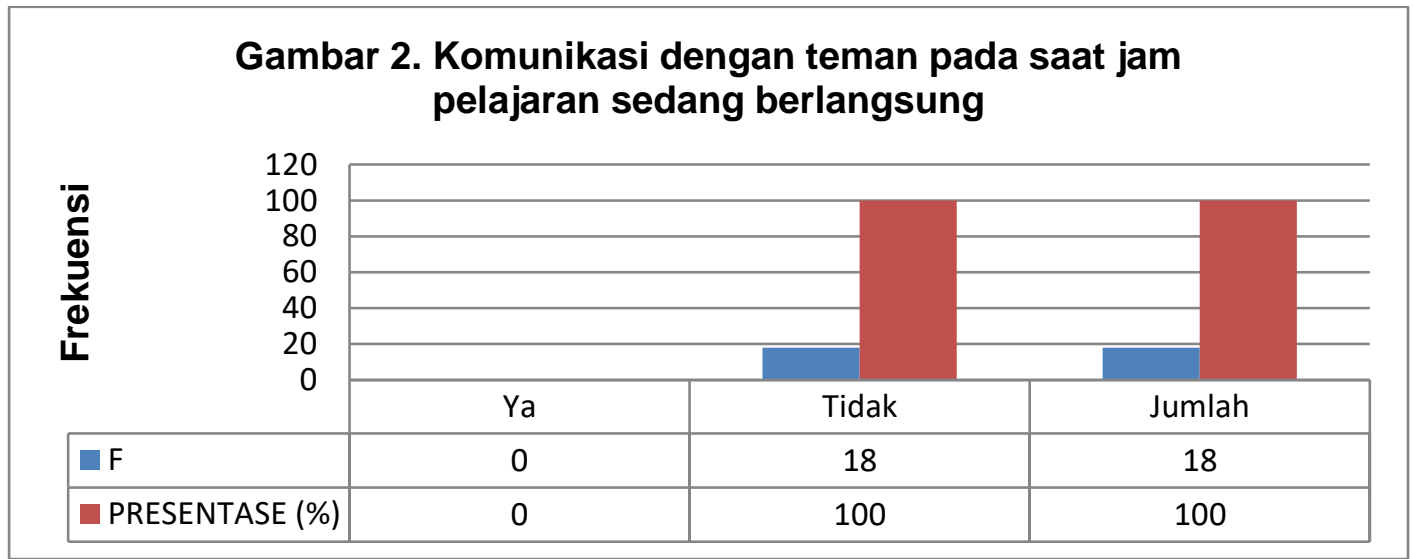

Sumber : Analisis Data Wawancara Responden 
Gambar. 2 yaitu tentang peserta didik yang berkomunikasi dengan teman pada saat jam pelajaran sedang berlangsung, dari data analisis tabel di atas menunjukkan bahwa terdapat 18 responden Tidak berkomunikasi dengan teman pada saat jam pelajaran sedang berlangsung atau $(100 \%)$. Alasannya karena menerima pelajaran lebih penting jika dibandingkan dengan chating sama teman pada saat jam pelajaran berlangsung. Karena anggapan mereka bahwa jika berkomunikasi dengan teman pada saat jam pelajaran berlangsung dapat menimbulkan masalah jika di ketahui oleh guru maka akan terkenal sanski. Sedangkan peserta didik yang berkomunikasi dengan teman pada saat jam pelajaran sedang berlangsung adalah 0 , maka dari tabel analisis di atas, penulis mengambil kesimpulan bahwa pada jam pelajaran sedang berlangsung peserta didik di larang untuk berkomunikasi dengan teman

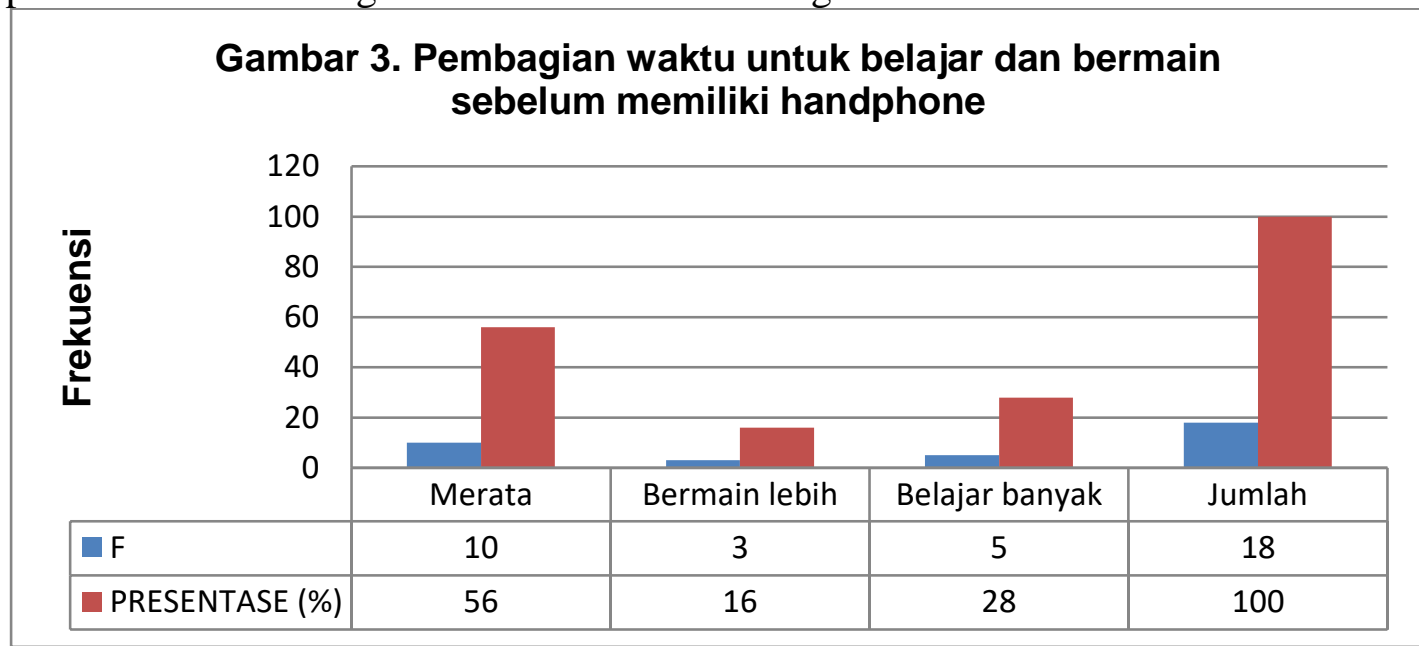

Sumber : Analisis Data Wawancara Responden

Gambar 3 yaitu tentang pembagian waktu belajar dan bermain sebelum memiliki handphone, dari data analisis tabel di atas terdapat 10 atau (56\%). Membagi waktu merata dengan alasan reponden dapat membagi waktu untuk bermain dan belajar, dengan alasan bahwa ada waktu untuk belajar dan ada waktu pula untuk chating dengan teman. Sedangkan peserta didik yang bermain lebih sebanyak 3 responden atau (16\%). Sementara responden yang belajar banyak yaitu 5 responden atau (28\%). Maka dari tabel analisis di atas peserta didik mengatakan bahwa cara membagi waktu untuk bermain dan belajar adalah dari pukul 03.00 siang sampai pukul 05.00 sore, untuk bermain, sedangkan jam belajar dari pukul 07.00 sampai dengan pukul 09.00 malam.

Berdasarkan penjelasan diatas maka penulis menarik kesimpulan bahwa siswa di SMA Yayasan Sub Byiaki Fyadi lebih mementingkan jam belajar dari pada chating dan keputusannya sama karena sebelum miliki handphone dan sesudah miliki handphone tetap sama keputusannya. 


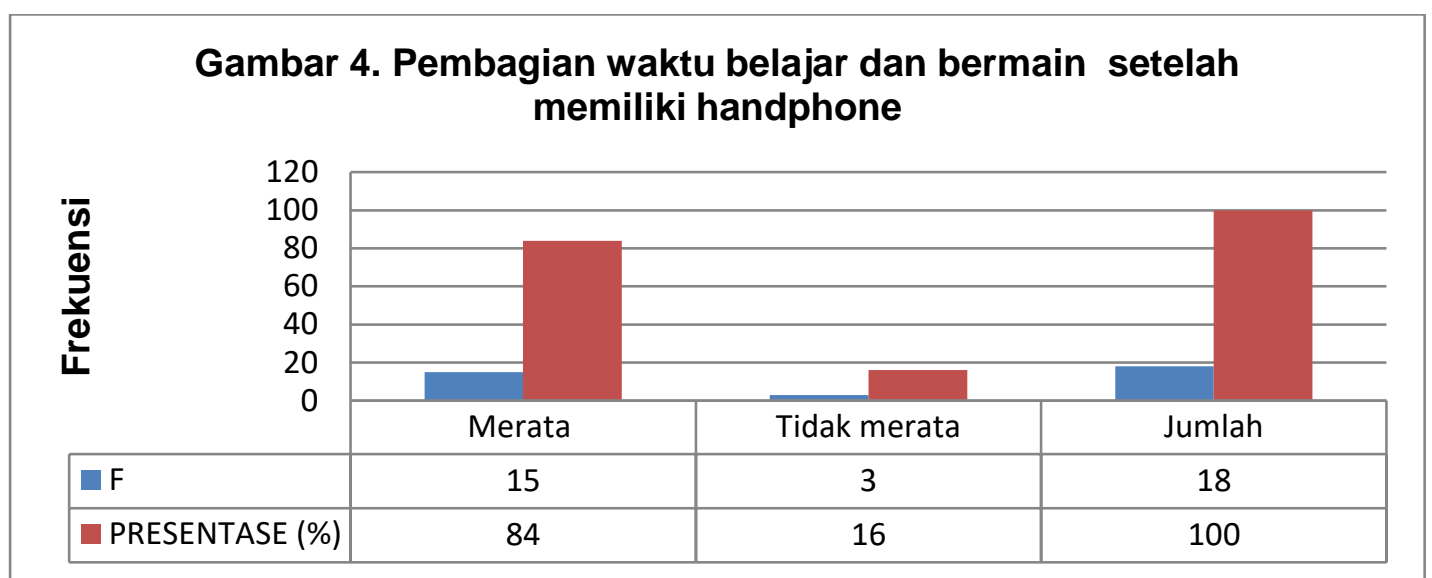

Sumber : Analisis Data Wawancara Responden

Gambar. 4 yaitu peserta didik setelah memiliki handphone,pembagian waktu untuk belajar dan berkomunukasi. Dari data analisis tabel di atas menunjukkan bahwa terdapat 15 reponden atau (84\%). Membagi waktu secara merata untuk bermain dan berkomunikasi. sedangkan peserta didik yang tidak membagi waktu untuk belajar sebanyak 3 responden atau (16\%). Maka dari tabel analisis di atas peserta didik mengatakan dengan jawaban yang sama bahwa pembagian waktu belajar dengan berkomunikasi dengan teman melalui ponsel adalah dari pukul 03.00 sampai denagn pukul 05.00 sore untuk bermain dan berkomunikasi dengan teman, sedangkan waktu untuk jam belajar dari Pukul 07.00 sampai dengan pukul 09.00 malam.

Alasannya sama yaitu pembagian waktu untuk belajar dan chating sangatlah penting untuk mereka karena bagi mereka tidak baik kalau komunikasi dan chating dilakukan pada saat menerima pelajaran atau pada saat belajar, karena akan hilang konsentrasi dalam menerima pelajaran dari guru.

\section{Bagi Orang Tua}

Dalam dunia pendidikan terlepas dari peran guru di sekolah maka peran orang tua sangatlah penting karena orang tua merupakan sosok yang penting bagi anak dalam mengembangkan pendidikan dalam keluarga, masyarakat, berbangsa dan bernegara. Olehnya itu orang tua sebagai ujung tombak bagi anak/peserta didik.

Berdasarkan data yang terkumpul melalui pedoman wawancara maka dapat di lihat hasil pengumpulan data yang terdapat pada tabel: 


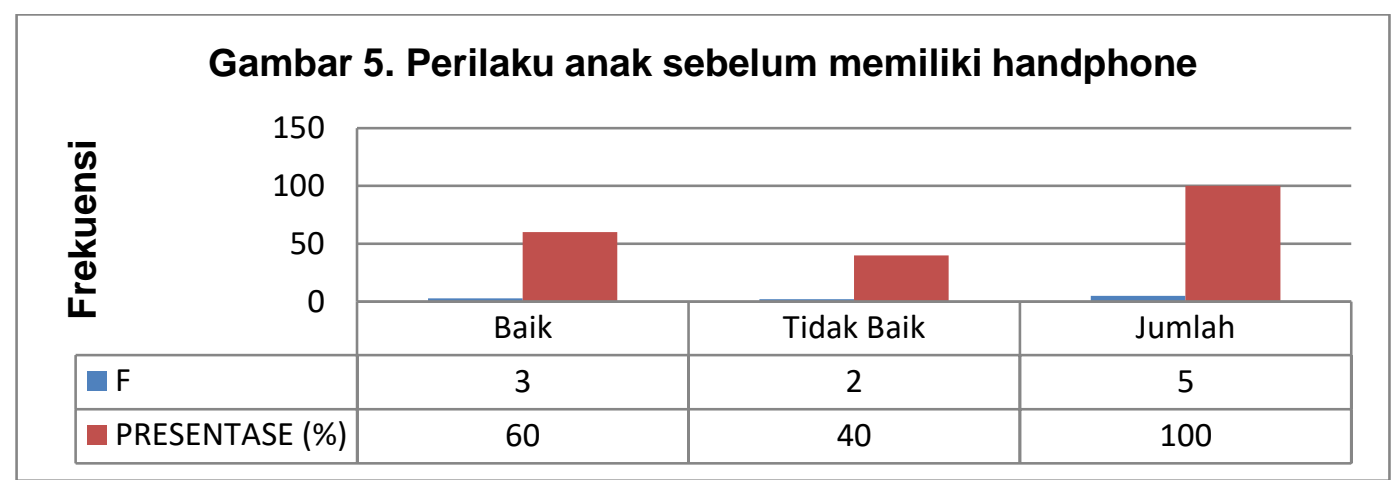

Sumber : Analisis Data Wawancara Responden

Data pada Gambar.5 diatas menyatakan tentang perilaku anak sebelum memiliki handphone. Dari data analisis tabel di atas menunjukkan bahwa terdapat 3 responden atau (60\%) yang menyatakan baik, sedangkan 2 responden atau (40\%) Dari data analisis tabel di atas, responden menyakan bahwa, perilaku anak sebelum memiliki ponsel, anak saya rajin belajar, rajin mengerjakan tugas-tugas yang di berikan oleh guru di sekolah.

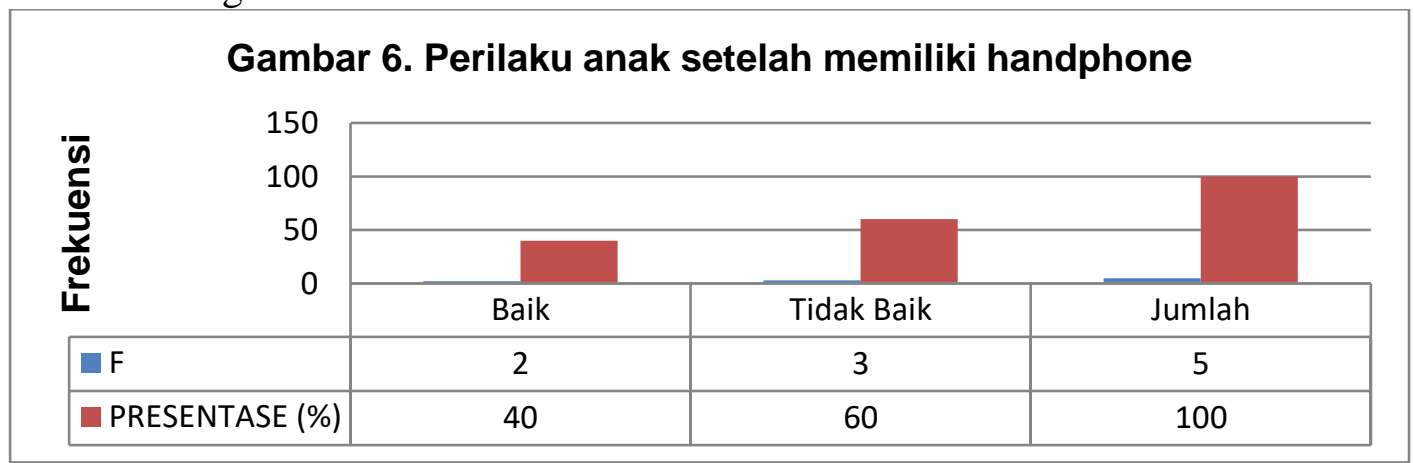

Sumber : Analisis Data Wawancara Responden

Data pada Gambar.6 yang menyatakan tentang perilaku anak setelah memiliki handphone. Dari data analisisis tabel di atas menunjukan bahwa terdapat 2 responden atau (40\%). Yang menyatakan baik. Sedangkan 3 responden atau (60\%). Dari data analisis tabel di atas responden menyatakan bahwa perilaku anak sesudah memiliki handphone, anak saya waktunya sangat sempit dan mulai mengurangi jam belajar bahkan lebih pokus pada handphone yang di gunakan. 


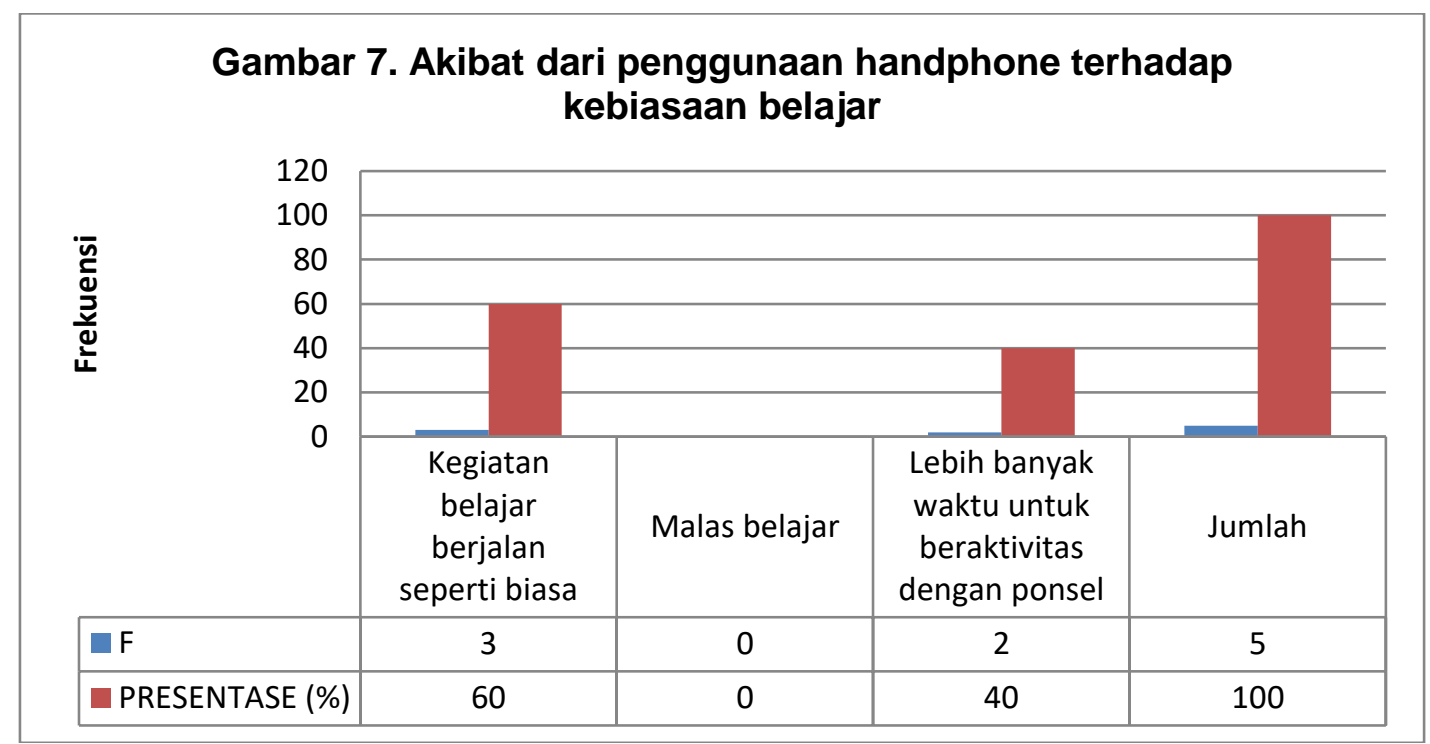

Sumber : Analisis Data Wawancara Responden

Data pada Tabel. 7 yang menyatakan bahwa akibat-akibat dari penggunaan handphone terhadap kebiasaan belajar. Dari data analisis tabel di atas menunjukkan bahwa terdapat 3 responden atau $(60 \%)$ yang menyatakan Baik, sedangkan 2 responden atau (40\%) Dari data analisis tabel di atas, responden menyakan bahwa kegiatan belajar mengajar seperti biasa karena anak tersebut rajin belajar, rajin mengerjakan tugas-tugas yang di berikan oleh guru sedagkan

Lebih banyak waktu untuk beraktivitas dengan pons karena anak ini mulai menggunakan ponsel maka ada kalanya dia suda lupa dengan jam belajarnya sehingga mengurangi jam belajar dan lebih fokus dengan ponsel yang di gunakannya.

Tabel. 8

Nilai-nilai pelajaran di sekolah sebelum memakai handphone

\begin{tabular}{|c|c|c|}
\hline $\begin{array}{c}\text { JAWABAN } \\
\text { RESPONDEN }\end{array}$ & F & PRESENTASE (\%) \\
\hline Baik & 3 & 60 \\
\hline Tidak Baik & 2 & 40 \\
\hline Jumlah & $\mathbf{5}$ & $\mathbf{1 0 0}$ \\
\hline
\end{tabular}

Sumber: Analisis Data Wawancara Responden

Pada Tabel. 8 yang menyatakan bahwa peserta didik sebelum yang memiliki nilai-nilai pelajaran di sekolah sebelum memiliki handphone. Dari data analisis tabel di atas menunjukkan bahwa terdapat 3 responden atau (60\%) yang menyatakan Baik, sedangkan 2 responden atau (40\%), dari data analisis tabel di atas, responden menyatakan bahwa, sebelum memiliki handphone nilai-nilai pelajarannya meningkat dan nilai-nilai yang di terima dari sekolah sangat baik dan sangat memuaskan. 
Tabel. 9

Nilai-nilai pelajaran di sekolah sesudah memakai handphone

\begin{tabular}{|c|c|c|}
\hline $\begin{array}{c}\text { JAWABAN } \\
\text { RESPONDEN }\end{array}$ & F & PRESENTASE (\%) \\
\hline Baik & 2 & 40 \\
\hline Tidak Baik & 3 & 60 \\
\hline Jumlah & $\mathbf{5}$ & $\mathbf{1 0 0}$ \\
\hline
\end{tabular}

Sumber : Analisis Data Wawancara Responden

Pada tabel. 9 yang menyatakan bahwa peserta didik yang memiliki nilai-nilai pelajaran di sekolah sesudah memiliki hanphone. Dari data analisis tabel di atas menunjukan bahwa terdapat 2 responden atau (40\%) yang menyatakan baik, sedangkan 3 responden atau (60\%). Dari data analisis tabel di atas, responden menyatakan bahwa, sesudah memiliki handphone, maka anak ini mempunyai konsentrasi belajar semakin menurun, bahkan nilai-nilai yang di terima dari pada para guru di sekolah tidak memuaskan.

Tabel. 10

Peran orang tua dalam mengatasi perilaku anak

\begin{tabular}{|c|c|c|}
\hline RESPONDEN & F & PRESENTASE (\%) \\
\hline Baik & 5 & 100 \\
\hline Tidak Baik & 0 & 0 \\
\hline Jumlah & $\mathbf{5}$ & $\mathbf{1 0 0}$ \\
\hline
\end{tabular}

Sumber : Analisis Data Wawancara Responden

Data pada Tabel.10 yang menyatakan bahwa peran orang tua dalam mengatasi perilaku anak. Dari data analisis tabel di atas menunjukkan bahwa terdapat 5 responden atau (100\%) yang menyatakan baik, sedangkan tidak baik 0 atau (0\%). Responden menyatakan bahwa perilaku anak baik, selaku orang tua memberikan arahan, nasehat serta motivasi yang baik kepada anak agar lebih banyak menggunakan waktu untuk belajar dan menyita handphone selama jam belajar, dan tidak boleh membawa handphone ke sekolah karena menganggu konsentrasi anak untuk belajar. 


\section{Bagi Guru dan Wali kelas}

Berdasarkan data yang terkumpul melalui pedoman wawancara maka dapat di lihat hasil pengumpulan data yang terdapat pada tabel:

Tabel. 11

Perilaku peserta didik sebelum memiliki Handphone

\begin{tabular}{|l|c|c|}
\hline \multicolumn{1}{|c|}{ JAWABAN RESPONDEN } & F & $\begin{array}{c}\text { PRESENTASE } \\
(\mathbf{\%})\end{array}$ \\
\hline Kegiatan belajar mengajar seperti biasa & 3 & 60 \\
\hline Malas belajar & 0 & 0 \\
\hline $\begin{array}{l}\text { Lebih banyak waktu untuk beraktivitas } \\
\text { dengan ponsel }\end{array}$ & 2 & 40 \\
\hline \multicolumn{1}{|c|}{ Jumlah } & $\mathbf{5}$ & $\mathbf{1 0 0}$ \\
\hline
\end{tabular}

Sumber : Analisis Data Wawancara Responden

Data pada Tabel. 11 yang menyatakan bahwa perilaku peserta didik sebelum dan sesuda memiliki handphone. Analisis tabel di atas menunjukkan bahwa terdapat 2 responden mengatakan kegiatan belajar mengajar peserta didik berjalan seperti biasa. Sedangkan perilaku peserta didik yang lebih banyak waktunya untuk beraktifitas dengan handphone sebanyak 3 responden atau (40\%). Yang menyatakan kegiatan belajar mengajar seperti biasa, sedangkan 3 responden atau $(60 \%)$ yang menyatakan Lebih banyak waktu untuk berktivitas dengan handphone. Analisis tabel di atas menunjukan bahwa responden yang menyatakan perilaku siswa sebelum memiliki ponsel kegiatan belajar mengajar seperti biasa dan nilai-nilai juga sangat baik.

Tabel. 12

Perilaku peserta didik sesudah memiliki handphone

\begin{tabular}{|l|c|c|}
\hline \multicolumn{1}{|c|}{ JAWABAN RESPONDEN } & F & $\begin{array}{c}\text { PRESENTASE } \\
(\mathbf{\%})\end{array}$ \\
\hline Kegiatan belajar mengajar seperti biasa & 2 & 40 \\
\hline Malas belajar & 0 & 0 \\
\hline $\begin{array}{l}\text { Lebih banyak waktu untuk beraktivitas } \\
\text { dengan ponsel }\end{array}$ & 3 & 60 \\
\hline \multicolumn{1}{|c|}{ Jumlah } & $\mathbf{5}$ & $\mathbf{1 0 0}$ \\
\hline
\end{tabular}

Sumber : Analisis Data Wawancara Responden

Data pada tabel . 12 yang menyatakan bahwa penjelasan guru tentang perilaku belajar peserta didik sesudah memiliki handphone. Analisis tabel di atas menunjukkan bahwa terdapat 2 responden Alasannya sesudah memiliki handphone nilai-nilai peserta didik agak menurun karena peserta didik sering menghabiskan waktu untuk bermain handphone sehingga banyak waktu tersita, akibatnya peserta didik mempunyai waktu sangat sedikit untuk belajar sehingga membuat prestasi belajar speserta didik menurun. 
Tabel. 13

Menggunakan Handphone pada saat jam pelajaran sedang berlangsung

\begin{tabular}{|c|c|c|}
\hline $\begin{array}{c}\text { JAWABAN } \\
\text { RESPONDEN }\end{array}$ & F & PRESENTASE (\%) \\
\hline Ya & 0 & 0 \\
\hline Tidak & 5 & 100 \\
\hline Jumlah & $\mathbf{5}$ & $\mathbf{1 0 0}$ \\
\hline
\end{tabular}

Sumber: Analisis Data Wawancara Responden

Tabel. 13 yaitu peserta didik yang menggunakan ponsel pada saat jam pelajaran sedang berlangsung. Analisis tabel di atas menunjukkan bahwa terdapat 5 responden atau (100\%) yang menyatakan Tidak, sedangkan peserta didikyang sering menggunakan ponsel pada saat jam pelajaran sedang berlangsung 0 atau (0\%).

Dari data analisis tabel di atas kesimpulanya bahwa peserta didik tidak ada yang berkomunikasi dengan teman selama jam pelajaran sedang berlangsung oleh karena itu peserta didik di larang untuk berkomuikasi dengan teman dan membawa ponsel ke sekolah karena dapat menggu konsentrasi untuk belajar.

Tabel. 14

Menggunakan Handphone untuk hal-hal yang negatif

\begin{tabular}{|c|c|c|}
\hline $\begin{array}{c}\text { JAWABAN } \\
\text { RESPONDEN }\end{array}$ & F & PRESENTASE (\%) \\
\hline Ya & 0 & 0 \\
\hline Tidak & 5 & 100 \\
\hline Jumlah & $\mathbf{5}$ & $\mathbf{1 0 0}$ \\
\hline
\end{tabular}

Sumber: Analisis Data Wawancara Responden

Data pada Tabel 14 yaitu penjelasan guru terkait peserta didik sering menggunakan ponsel untuk hal-hal yang negatif. Analisis tabel di atas menunjukkan bahwa terdapat 5 responden atau (100\%) yang menyatakan Tidak, sedangkan peserta didik yang sering menggunakan handphone untuk hal-hal negative 0 atau $(0 \%)$.

Dari data analisis tabel di atas kesimpulannya adalah Tidak ada peseta didik yang menggunakan ponsel untuk hal-hal yang negatif, karena peserta didik sering menggunakan ponsel untuk mengerjakan tugas dan bertukar informasi dengan orang lain (teman dan lain-lain)

Tabel. 15

Menggunakan handphone untuk mengerjakan tugas-tugas belajar

\begin{tabular}{|c|c|c|}
\hline $\begin{array}{c}\text { JAWABAN } \\
\text { RESPONDEN }\end{array}$ & F & PRESENTASE (\%) \\
\hline Ya & 5 & 100 \\
\hline Tidak & 0 & 0 \\
\hline Jumlah & $\mathbf{5}$ & $\mathbf{1 0 0}$ \\
\hline
\end{tabular}

Sumber: Analisis Data Wawancara Responden 
Tabel 15 yaitu tentang penggunaan handphone untuk mengerjakan tugas-tugas belajar. Analisis tabel di atas terdapat 5 responden yang menyatakan Apakah peserta didik menggunakan ponsel untuk mengerjakan tugas-tugas belajar atau (100), yang menyatakan Ya, sedangkan siswa yang menggunakan ponsel untuk tidak mengerjakan tugas-tugas 0 atau $(0 \%)$. Dari data analisis tabel di atas menyatakan bahwa karena dengan mengakses tugas-tugas dengan ponsel lebih cepat di dapat.

Tabel. 16

Nilai-nilai pelajaran di sekolah sebelum memiliki handphone

\begin{tabular}{|c|c|c|}
\hline $\begin{array}{c}\text { JAWABAN } \\
\text { RESPONDEN }\end{array}$ & F & PRESENTASE (\%) \\
\hline Baik & 3 & 60 \\
\hline Tidak Baik & 2 & 40 \\
\hline Jumlah & $\mathbf{5}$ & $\mathbf{1 0 0}$ \\
\hline
\end{tabular}

Sumber: Analisis Data Wawancara Responden

Data pada Tabel 16 yaitu penjelasan guru tentang nilai-nilai pelajaran di sekolah sebelum dan sesudah memiliki ponsel. Dari data analisis tabel di atas menunjukkan bahwa terdapat 3 responden atau (60\%) yang menyatakan Baik, sedangkan nilai-nilai pelajaran di sekolah sesudah memiliki ponsel terdapat 2 responden atau (40\%) yang menyatakan Tidak Baik. Maka data analisis pada tabel di atas menjadi kesimpulan bahwa peserta didik sebelum memiliki handphone untuk kategori nilai-nilai tugas cukup dan semakin membaik nilai-nilai ada peningkatan pada uraian tugas, nilai-nilai mit dan nilai uas.

Tabel. 17

Nilai-nilai pelajaran di sekolah setelah memiliki handphone

\begin{tabular}{|c|c|c|}
\hline $\begin{array}{c}\text { JAWABAN } \\
\text { RESPONDEN }\end{array}$ & F & PRESENTASE (\%) \\
\hline Baik & 2 & 40 \\
\hline Tidak Baik & 3 & 60 \\
\hline Jumlah & $\mathbf{5}$ & $\mathbf{1 0 0}$ \\
\hline
\end{tabular}

Sumber: Analisis Data Wawancara Responden

Data pada Tabel 17 yaitu tentang nilai-nilai pelajaran di sekolah setelah memiliki handphone. memiliki handphone, Dari data analisis tabel di atas menunjukkan bahwa terdapat 2 responden atau (40\%) yang menyatakan Baik, sedangkan nilai-nilai pelajaran di sekolah sesudah memiliki ponsel terdapat 3 responden atau $(60 \%)$ yang menyatakan Tidak Baik. Maka data analisis tabel di atas menjadi kesimpulan bahwa peserta didik setelah memiliki handphone nilai-nilai tugas cukup, tetapi ada juga yang tidak, nilai-nilai mit dan uas nilainya kurang memuaskan tetapi ada juga peserta didik yang nilai-nilainya baik dan memuaskan, jadi tergantung pribadi masing-masing peserta didik.

\section{PEMBAHASAN}

Berdasarkan hasil analisis terhadap hasil jawaban yang diberikan responden, terdapat beberapa variabel 1) Penggunaan Handphone dan akibat-akibat yang 
disebabkan seperti, jenis handphone, penggunaan fitur dalam handphone, waktu chating, 2) Penyalahgunaan fitur-fitur, 3) Fungsi kontrol orang tua terhadap anak, 4) Fungsi kontrol guru terhadap peserta didik di sekolah.

Sesuai dengan hasil penilitian yang di lakukan penulis, dapat di katakan dari jumlah peserta didik yang di wawancarai penulis terdapat 18 orang yang memiliki handphone dengan jenis handphone yang berbeda-beda. Pada tabel 6 terdapat 8 orang yang memiliki handphone jenis nokia, 5 orang jenis Samsung dan 5 orang jenis bacbery. Kemudian fitur-fitur dalam handphone terdapat 5 orang yang menggunakan fitur BBM, 10 orang memiliki fitur facebook, dan 3 orang memiliki game. Dari fitur yang sering digunakan yang menjadi alasan mendasar responden untuk menggunakan fitur facebook, BBM, yaitu untuk berkomunikasi dengan teman, saudara, keluarga, kerabat dan handai tolan. Sedangkan yang menggunakan game untuk refresing. Hal ini sependapat dengan Goran Hedebro (1982) yang menyatakan bahwa komunikasi menggunakan makna pertukaran pesan, komunikasi ada pada semua usaha yang bertujuan kearah perubahan. Walaupun komunikasi hadir dengan tujuan membawa perubahan, tetapi bukan alasan utama dalam perubahan sosial. Hanya saja, komunikasi merupakan salah satu faktor yang menimbulkan perubahan masyarakat.

Sejalan dengan hal itu peserta didik pun mempunyai tugas untuk menjaga hubungan baik dengan guru maupun dengan sesama temannya dan untuk senantiasa meningkatkan keefektifan belajar bagi kepentingan dirinya sendiri.Adapun tugas tersebut ditinjau dari berbagai aspek yaitu aspek yang berhubungan dengan belajar, aspek yang berhubungan dengan bimbingan, dan aspek yang berhubungan dengan administrasi.

1. Aspek yang berhubungan dengan belajar

Kesalahan-kesalahan dalam belajar sering dilakukan murid, bukan saja karena ketidaktahuannya, tetapi juga disebabkan oleh kebiasaan-kebiasaannya yang salah, adalah menjadi tugas murid untuk belajar baik yang menghindari atau mengubah cara-cara yang salah itu agar tercapai hasil belajar yang maksimal.

Hal-hal yang harus diperhatikan murid agar belajar menjadi efektif dan produktif, di antaranya:

a. Murid harus menyadari sepenuhnya akan arah dan tujuan belajarnya, sehingga ia senantiasa siap siaga untuk menerima dan mencernakan bahan. Jadi bukan belajar asal belajar saja.

b. Murid harus memiliki motif yang murni (intrinsik atau niat). Harus belajar dengan "kepala penuh", artinya murid memiliki pengetahuan dan pengalaman-pengalaman belajar sebelumnya (apersepsi), sehingga memudahkan dirinya untuk menerima sesuatu yang baru.

c. Murid harus menyadari bahwa belajar bukan semata-mata mengahafal. Di dalamnya juga terdapat penggunaan daya-daya mental lainnya yang harus dikembangkan sehingga memungkinkan dirinya memperoleh pengalamanpengalaman baru dan mampu memecahkan berbagai masalah.

d. Harus senantiasa memusatkan perhatian (konsentrasi pikiran) terhadap apa yang sedang dipelajari dan berusaha menjauhkan hal-hal yang mengganggu 
konsentrasi sehingga terbina suasana ketertiban dan keamanan belajar bersama dan/atau sendiri.

e. Harus memiliki rencana belajar yang jelas, sehingga terhindar dari perbuatan belajar yang "insidental". Jadi belajar harus merupakan suatu kebutuhan dan kebiasaan yang teratur, bukan "seenaknya" saja.

f. Murid harus memandang bahwa semua ilmu (bidang studi) itu sama penting bagi dirinya, sehingga semua bidang studi dipelajarinya dengan sungguhsungguh. Memang mungkin saja ada "beberapa" bidang studi yang ia "senangi", namun hal itu tidak berarti bahwa ia dapat mengabaikan bidang studi yang lainnya.

g. Jangan melalaikan waktu belajar dengan membuang-buang waktu atau bersantai-santai. Gunakan waktu seefesien mungkin dan hanya bersantai sekadar melepaskan lelah atau mengendorkan uraf saraf yang telah tegang dengan berekreasi.

h. Harus dapat bekerja sama dengan kelompok/kelas untuk mendapatkan sesuatu atau memperoleh pengalaman baru dan harus teguh bekerja sendiri dalam membuktikan keberhasilan belajar, sehingga ia tahu benar akan batas-batas kemampuannya. Meniru, mencontoh atau menyontek pada waktu mengikuti suatu tes merupakan perbuatan tercela dan merendahkan "martabat" dirinya sebagai murid.

i. Selama mengikuti pelajaran atau diskusi dalam kelompok/kelas, harus menunjukkan partisipasi aktif dengan jalan bertanya atau mengeluarkan pendapat, bila diperlukan.

\section{Aspek yang Berhubungan dengan Bimbingan}

Semua murid harus mendapat bimbingan, tetapi tidak semua murid khususnya yang bermasalah, mempergunakan haknya untuk memperoleh bimbingan khusus. Hal itu mungkin disebabkan oleh karena berbagai "perasaan" yang menyelimuti murid, atau karena ketidaktahuannya, dan mungkin juga disebabkan oleh karena guru/sekolah tidak membuka kesempatan untuk itu, dengan berbagai alasan.

Guru berkewajiban memperhatikan masalah ini dan menjelaskan serta memberi peluang kepada murid untuk memperoleh bimbingan dan penyuluhan. Jika hal itu telah disampaikan guru dengan lurus dan benar, maka menjadi tugas muridlah kini untuk mempergunakan hak-haknya dalam mendapatkan bimbingan/penyuluhan.

Kesadaran murid akan guna bimbingan belajar serta bimbingan dalam bersikap, agar dirinya dapat menyesuaikan diri dengan lingkungan serta melaksanakan sikap-sikap yang sesuai dengan ajaran agama dalam kehidupannya sehari-hari, amat diharapkan. Dan untuk itu, maka menjadi tugas muridlah untuk berpartisipasi secara aktif, sehingga bimbingan itu dapat dilaksanakan secara efektif.

Sehubungan dengan penggunaan fitur dalam mengakses data yaitu seperti mencari ilmu pengetahuan terdapat 5 orang responden, sedangkan nonton filem-filem dengan cerita menarik terdapat 10 orang responden. Waktu yang di gunakan untuk chating yang paling lama lebih dari 2 jam, hal ini terjadi apabila mendapat teman baru di akun facebook atau BBM sehingga menggunakan waktu yang cukup lama atau ada 
teman yang sudah lama baru ketemu lewat dunia maya sehingga membuat chating semakin lama. Walaupun peserta didik menggunakan waktu chating yang begitu laman namun waktu untuk belajar juga tetap ada dan tidak berkomunikasi melalui handphone pada saat jam pelajaran sedang berlangsung di sekolah.

\section{Dampak Positif Penggunaan Handphone Bagi Pelajar} lain: Berikut adalah dampak positif pengggunaan handphone bagi pelajar antara

1. Mempermudah komunikasi (Melakukan komunikasi dengan orang tua).

2. Peran ini memang vital terutama bagi siswa yang relatif jauh rumahnya dari sekolah dan ada kendala transportasi. Untuk itu peranan HP sangat penting sekali untuk memastikan kapan dan kapan jemputan diperlukan.

3. Mencari informasi IPTEK lewat internet, hal ini dimungkinkan dengan penemuan seri HP canggih generasi $3 \mathrm{G}$ yang memberikan kesempatan penggunanya untuk browsing internet lewat Handphone

4. Memperluas jaringan persahabatan dengan mengakses jejaring sosial yang bisa kita dapatkan dengan mendownload aplikasi java yang sesuai dengan handphone kita.

5. Mempermudah kegiatan belajar, handphone yang dilengkapi feature seperti Document Viewer dapat membantu pelajar dalam mempelajari materi dalam bentuk ebook atau pdf secara portable dengan mudah.

6. Membantu pelajar untuk berlatih English conversation dengan format Mp3 atau Mp4.

7. Menghilangkan kepenatan pelajar setelah belajar dengan mendengarkan music dengan feature Mp3 player atau radio Fm.

\section{Dampak Negatif Penggunaan Handphone Bagi Pelajar}

Dampak penggunaan HP terhadap pelajar itu sangat membahayakan jika digunakan dengan maksud yang tidak jelas dan dapat merugikan baik diri sendiri maupun orangtua.Guru juga sangat dirugikan oleh HP. HP dapat menghambat pemberian pelajaran kepada para pelajarnya. Dampak negatif yang ditimbulkan oleh HP :

1. Konsentrasi belajar menurun

Konsentrasi terhadap pelajaran menjadi berkurang karena lebih mementingkan HP mereka yang digunkan untuk ber-sms sama teman maupun membalas sms dari teman. Terlebih lagi sekolah yang memiliki pengawasan yang kurang ketat sehingga para siswa memiliki waktu luang untuk ber-sms.

Waktu belajar pun banyak digunakan untuk bermain handphone ataupun bersmsan, selain itu waktu malam hari yang biasanya dahulu digunakan para pelajar untuk belajar sekarang malah digunakan telepon-teleponan dan bersmsan. Bermain game saat guru menjelaskan pelajaran merupakan bukti nyata bahwa HP mudah mengalihkan perhatian peserta didik terhadap pelajaran. 
2. Mengganggu Perkembangan Anak :

a. Fitur-fitur yang tersedia di HP seperti : kamera, games, gambar, dan fasilitas yang lain, mudah mengalihkan perhatian siswa dalam menerima pelajaran di sekolah (kelas).

b. Siswa mudah disibukkan dengan memanggil/ menerima panggilan, sms, miscall dari teman mereka bahkan dari keluarga mereka sendiri.

c. Lebih parah lagi dengan HP dapat untuk melakukan kecurangan dalam ulangan.

d. Dengan HP peserta didik dapat mudah mengirim/ menerima baik tulisan maupun gambar yang tidak senonoh dan tidak selayaknya dikonsumsi pelajar tingkat SMP. Kalau hal tersebut dibiarkan, maka peserta didik akan dewasa sebelum waktunya, dan peserta didik yang kita hadapi merupakan peserta didik yang taat dan patuh pada permainan teknologi HP.

\section{Pengeluaran menjadi bertambah / boros}

Dengan anggaran orang tua yang serba minim para siswa memaksa orang tuanya untuk dapat dibelikan HP. Belum lagi para pelajar setelah itu harus meminta uang kepada orangtua untuk membeli pulsa setip bulan bahkan setiap hari. Apalagi dengan canggihnya handphone-handphone zaman sekarang yang bisa dengan mudahnya berselancar di dunia maya itu pun berpengaruh dengan pengeluaran yang menjadi bertambah Dari yang biasanya habis pulsa lima puluh ribu perbulan menjadi lebih dari seratus ribu rupiah agar bisa menikmati akses internet dan akses jejaring sosial tanpa batas pemakaian. Hp yang dipakai pun semakin canggih dan semakin sering diisi baterainya sehingga akan lebih boros listrik.

Kebanyakan pelajar sekarang itu tidak mempunyai buku dengan alasan tidak punya uang, tetapi dibalik itu kalau urusan " membeli pulsa" tidak ada kata " tidak punya uang “"

Sangat berpotensi mempengaruhi sikap dan perilaku siswa. Jika tidak ada kontrol dari guru dan orang tua.HP bisa digunakan untuk menyebarkan gambargambar yang mengandung unsur pornografi.Ini adalah akibat yang paling berbahaya dalam penggunaan HP oleh para pelajar.Mereka menggunakan HP dengan tujuan yang menyimpang contohnya seperti mengisi video porno kedalam HP dan menggunakan kata-kata yang tidak senonoh.

4. Rawan terhadap tindak kejahatan.

Pelajar merupakan salah satu target utama dari pada penjahat. Apalagi handphone merupakan perangkat yang mudah dijual, sehingga, anak-anak yang menenteng handphone bisa-bisa dikuntit maling yang mengincar handphonenya.

\section{KESIMPULAN DAN SARAN Kesimpulan}

Dari berbagai analisis data serta pembahasan yang telah dipaparkan maka kesimpulan yang diambil yaitu: 
Penggunaan hanphone bagi peserta didik ada baiknya, akan tetapi ada juga buruknya. Baiknya itu jika peserta didik yang menggunakan handphone sesuai dengan fungsinya seperti, sms sama teman, sahabat serta untuk mencari tugas-tugas sekolah yang diberikan dari guru kepada peserta didik. Namun selain manfaat yang baik juga pasti ada buruknya seperti setiap jam pelajaran ada peserta didik yang main handphone di belakang dan tidak mendengar penyampaian materi dari guru. Kemudian setelah memiliki handphone sudah jarang belajar karena kebanyakan waktu disita oleh handphone.

Sehingga orang tua sebagai pengayom bagi anak harusnya tegas dalam mendidik dan mendewasakan anak-anak karena, perkembangan jaman sekarang sudah jaman digital, sehingga orang tua harus memiliki peran penting dalam segala hal. Karena jika orang tua lalai maka anak akan terjerumus ke dalam arus jaman yang sangat kuat.

Terlepas dari peran orang tua juga tak kalah pentingnya peran guru di sekolah dalam mendidik anak-anak karena guru adalah orang tua pserta didik di sekolah. Peserta didik yang sering menggunakan handphone tidak pada tempatnya maka, harus di beri sanksi agar peserta didik sadar akan apa yang dilakukan olehnya itu salah.

\section{Saran}

Berdasarkan kesimpulan diatas maka saran yang diberikan adalah:

1. Wali kelas harus tingkatkan perannya dalam membina peserta didik agar tidak selalu fokus pada handphone tetapi harus fokus pada pelajaran yang diberikan dari guru.

2. Guru Bimbingan Konseling harus selalu aktif dalam pemberian layanan bimbingan belajar, agar peserta didik dapat mengembangkan prestasinya di masing-masing bidang yang dia sukai.

3. Orang tua harus banyak memberikan nasihat kepada anak agar anak tidak menghabiskan waktu dengan handphone, akan tetapi lebih fokus pada pelajaran yang diberikan guru. Bahkan lebih banyak dengan buku atau hal-hal yang bersifat baik seperti menggunakan handphone untuk mencari tugas dan lain-lain.

4. Peserta didik harus terus belajar agar mendapatkan prestasi yang baik sehingga dapat menjadi bekal nanti bagi masa depan.

\section{DAFTAR RUJUKAN}

Arikunto, Suharsimi. 2010. Prosedur Penelitian Suatu Pendenkatan Praktik. Jakarta: Rinekacipta.

Dekinus Kogoya, 2015 Dampak Penggunaan Handphone Pada Masyarakat Studi Pada Masyarakat Desa Iungun Kecamatan Gamelia Kabupaten Lanny Jaya Papua, e-journal "Acta Diurna” Volume IV. No.4. Tahun 2015

Fuadi, Arifin. 2010. Pengaruh Tingkat Keseringan Menonton Televisi Pada Jam Belajar dan Kontrol Orang Tua dengan Perilaku Belajar Siswa SMP 
Muhammadyah 1 Sragen Tahun Ajaran 2008/2009. Skripsi Universitas Sebelas Maret Surakarta.

Hanifah. 2001. Pengaruh Perilaku Belajar Terhadap Prestasi Akademik Mahasiswa Akuntansi. Dalam jurnal Media Riset Akuntansi, Auditing, dan Informasi. Vol1. No.3 desember 2001

Mardiana, Nana. 2012. Upaya Guru Meningkatkan Perilaku Belajar Siswa Mata Pelajaran IPS Terpadu di SMP. Dalam jurnal penelitian pendidikan universitas Tanjung Pura Pontianak.

Nikmah, A. 2013 Dampak Penggunaan Handphone Terhadap prestasi Siswa, E-Jurnal Dinas Pendidikan Kota Surabaya, 5:1-8.

Nurudin. Sistem-Sistem Komunikasi di Indonesia. Jakarta : PT RajaGrafindo Persada, 2005.

Simanjuntak, Fritz E. Aspek Sosial Telepon Selular. www.kompas.com. 13 Mei 2004.

Syah, Muhibbin. 2008. Psikologi Pendidikan Dengan Pendekatan Baru. Bandung: Remaja Rosdakarya. 